\title{
OLIVE MILLS WASTE: POLLUTION THREATS FOR WATERSHED IN JORDAN
}

\author{
Nidal Mahmoud \\ Institute of Environmental and Water Studies (IEWS), Birzeit University, P.O. \\ Box 14, Birzeit, the West Bank, Palestine
}

Adriaan Mels

Lettinga Associates Foundation (LeAF), PO Box 500, 6700, AM Wageningen, The Netherlands

Jules B. van Lier

Section Sanitary Engineering, Department of Water Management, Faculty of Civil Engineering and Geosciences, Delft University of Technology, Delft, The

Netherlands

\begin{abstract}
Jordan watersheds heavily suffer from the seasonal discharge of highly concentrated olive mill wastewater (OMW). Environmental concern and protection of the scarcely available water resources calls for adequate treatment of OMW prior to discharge. This paper describes an inventory that was made with the aim of developing pollution prevention strategies for the olive mill sector of the Jerash Governorate in Jordan. In the present work, an inventory was made of the Jerash Governorate olive mills with emphasis on the production methods and presenting the concomitant pollution loads coming from selected mills. Methods which can reduce water consumption based on cleaner production principles are presented.
\end{abstract}

\section{KEYWORDS}

Anaerobic treatment; olive mill wastewater; UASB; watershed protection; sustainable development; treatment strategy; conservation

\section{BACKGROUND}

Olive mill wastes are increasingly recognised as one of the most serious environmental threats in the Mediterranean region, where almost the entire world's production of olive oil is located [1-3]. It is estimated that around 30 million cubic meter of olive mill wastewater (OMW) is generated annually in the Mediterranean area, during the seasonal extraction of olive oil [4-6]. The discharge of high loads of organic pollutants, nutrients and polyphenolic components to surface and ground water raises concerns about possible negative effects of OMW discharge on the environment [6]. Proper treatment and disposal of OMW is presently high on the agenda in the Mediterranean countries, such as Spain, Italy, Greece, and Tunisia as well as in Jordan, the focus country of this study.

In Jordan, which is a (semi-)arid country, water resources are scarce and traditional water supply resources are being stretched to their maximum limits. Therefore, protection of water resources from pollution is a vital issue to achieve sustainable development. The Jordan valley 
and its tributaries are the most potential areas for development, especially in the field of agriculture. However, the natural resources, e.g. surface and groundwater, of the Jordan River basin are threatened by weak management. Therefore, severe deterioration of these resources is expected on the mid-long term if no appropriate measures are taken.

OMW is one of the most severe polluting streams affecting the Jordan Valley watershed. In Jordan, the area planted with olive trees has increased significantly from 285 million $\mathrm{m}^{2}$ in 1984 [7] to 644.8 million $\mathrm{m}^{2}$ in the year 2002. In the year 2000 , olive trees formed $73 \%$ of total area planted with fruit trees in Jordan [8]. More than $13 \%$ of the total number of olive trees (8.57 million trees) is found in Jerash Governorate, located in the northern parts of Jordan. In the present work, an inventory was made of the Jerash Governorate olive mills with emphasis on the production methods and presenting the concomitant pollution loads coming from selected mills. Methods which can reduce water consumption based on cleaner production principles are presented. The research was performed in Al-Merad, Burma and AlMastaba watershed areas in Jerash and was accomplished by means of interviews with local stake holders, field visits and literature search.

\section{OLIVE MILL PROCESSING AND ITS RELATED ENVIRONMENTAL PROBLEMS}

\subsection{Olive mill processing}

Olive mill processing in Jerash governorate has increased substantially in size during the last four decades. At present, all traditional milling methods have been replaced by full automatic three phase decanters. The three-phase decanter requires the addition of water during processing (see Figure 1) and is characterised by 3 products: oil, wastewater and dry solids (pomace). The added water eventually constitutes the largest fraction of the wastewater, presented as wastewater flow (3) in Figure 1. This flow includes the water soluble organic compounds, like the refractory polyphenols, leading to environmental constraints. In addition to the high environmental impacts of using the three phase decanter, the high water consumption also reduces the quality of the produced oil. Considering these negative aspects, it might be more rational for Jerash olive mills to use the more recently developed, environmental friendly, two-phase decanter. The two-phase decanter is characterised by only oil and wet pomace as products and was developed based on cleaner production principles to reduce water consumption and wastewater production (see Table 1).

Table 1. Advantages and disadvantages of the two-phase decanter as compared with the three-phase decanter $[9,10]$.

\begin{tabular}{|c|c|}
\hline Advantages & Disadvantages \\
\hline $\begin{array}{l}\text { - Does not require the addition of water } \\
\text { in most cases, } \\
\text { - Generates } 5 \text { times less wastewater, } \\
\text { i.e., } 0.25 \mathrm{~L} / \mathrm{kg} \text { of olives processed, } \\
\text { - No dilution of the polyphenol content, } \\
\text { resulting in high quality olive oil and } \\
\text { less negative impact on the } \\
\text { environment, } \\
\text { - Water and energy saving, up to } 80 \% \\
\text { and } 20 \% \text {, respectively. }\end{array}$ & $\begin{array}{l}\text { - Sacrificing part of its extraction } \\
\text { capacity, i.e. less olive oil / kg olives } \\
\text { processed, } \\
\text { - The decanter coil expels the water } \\
\text { together with the pomace, resulting in } \\
\text { a more hazardous and wet pomace. }\end{array}$ \\
\hline
\end{tabular}


The development of the two-phase decanter process was supported by national policies in Spain, aiming at costs minimizing in wastewater handling and disposal. It currently is the established process with over $90 \%$ of olive oil recovery $[9,11]$. As an in-between technology, the two and a half phase oil decanter was developed, which is a compromise between the two previous types of decanters. The two and a half phase decanter is in essence a three phase decanter that separates the oil paste into the standard three phases, but instead of adding external water to the process, the vegetation water indicated as wastewater stream (2) in Figure 1 , is internally recirculated. Consequently, the two and a half phase decanter has a lower water requirement and thus a lower wastewater production. Therefore, the water content of the obtained pomace comes very close to that of the standard three-phase decanter, but the wastewater output is relatively small and thus minimizing the residue management issues $[12,13]$. Three-phase decanters can be easily modified to two-phase decanters.



Figure1. Processing steps in the three-phase decanters, like those used by Jerash Olive Mills, and water and wastes production routes

\subsection{Specific pollution load of OMW}

Balice et al. [14] showed, through analysing OMW samples collected from 37 olive mills of different types, that the composition of OMW, concentrations and specific volumes (per unit mass of processed olives) are quite variable and apparently dependent on the type of extraction process. The polluting organic load per unit weight of processed olives, however, is practically independent of the extraction system, and amounts to $100-120 \mathrm{~kg}$ chemical oxygen demand (COD)/ ton of processed olives. This is equivalent to $45-55 \mathrm{~kg}$ biological oxygen demand $\left(\mathrm{BOD}_{5}\right) /$ ton of processed olives. The concentration of a specific OMW can therefore be derived from the load and the flow rate of washing waters from the mill. A rough calculation of the specific organic load per unit weight and estimated yearly pollution load of processed olives in Jerash Governorate is presented in Table 2.

2.3 Effects of olive mill effluents on sewers, wastewater treatment plants and soils

The difficulties in disposing of OMW are mainly related to $[15,16]$ : 
1. High concentrations of several organic compounds including sugars, nitrogenous compounds, tannins, pectins, volatile acids, polyalcohols, oil and phenolic substances, resulting in a high COD and BOD. The concentrations are generally in the range of $50-150 \mathrm{~g} / \mathrm{L}$ for COD and 12-63 $\mathrm{g} / \mathrm{L}$ for BOD and thus, form important potential threat to surface and ground water sources,

2. The nature of some constituents; it has been reported that the polyphenolic components in OMW are responsible for its high phytotoxicity and bactericidal activity,

3. The seasonal production, which in the Mediterranean area lasts around 3.5 months per year (mid October till end of January).

Table 2. Specific organic pollution load per unit weight of processed olives of two olive mills in Jerash Governorate, Jordan and the concomitant estimated yearly pollution load

\begin{tabular}{|c|c|c|c|}
\hline Olive mill & $\begin{array}{l}{ }^{+} \text {Specific } \text { OMW } \\
\text { production }\end{array}$ & ${ }^{++}$Specific organic load & $\begin{array}{c}\text { Estimated } \\
\text { yearly } \\
\text { pollution } \\
\end{array}$ \\
\hline$\#$ & $\begin{array}{l}\mathrm{m}^{3} / \text { ton of } \\
\text { processed olives }\end{array}$ & $\begin{array}{ll}\mathrm{Kg} \mathrm{COD} / \text { ton of } & \mathrm{Kg} \mathrm{BOD}_{5} / \text { ton } \\
\text { processed olives } & \text { of processed } \\
& \text { olives }\end{array}$ & $\begin{array}{l}\text { thousand ton } \\
\text { of } \mathrm{BOD}_{5}\end{array}$ \\
\hline 1 & 1.25 & 146 & 1.22 \\
\hline 2 & 1.1 & 129 & 1.07 \\
\hline
\end{tabular}

The effects of olive mills effluents on sewers can be quite severe, and are related to the acidity and the suspended solids contents. Because of the high concentration of organic acids (mainly volatile fatty acids), olive mill effluents are very corrosive. Extensive damages to sewerage systems by OMW have been reported [2]. The high suspended solids concentration in OMW eventually may lead to clogging because of solids settling in the sewers close to the mills discharge pipes. The sediments, from both OMW and domestic wastewater, undergo anaerobic fermentation, resulting in the escape of foul odours and an increase in the acidity of the wastewater [2].

The main effects of OMW on municipal wastewater treatment plants are related to their concentration, composition and to their seasonal production [1]. OMW is one of the most polluting agro-industrial residues. Relatively small spills of olive mill effluents into the sewers have appreciable effects on the organic loading of wastewater treatment plants, as the pollution load due to $1 \mathrm{~m}^{3}$ of OMW corresponds to $100-200 \mathrm{~m}^{3}$ of domestic sewage. In addition, OMW may cause problems because of its composition, such as the considerable concentration of slowly biodegradable compounds (such as tannins) that give a dark-red to black colour which is difficult to remove from the effluent, low $\mathrm{pH}$ values, high phenols concentration which might be toxic to micro organisms in domestic wastewater treatment plants, etc $[1,17]$. 
The practice of spreading OMW directly on agricultural soils must be accomplished with great vigilance, since it may result in more damage than beneficial effects on soil fertility, again due its high concentration of organic pollutants and solids [6]. The indigenous knowledge in Jerash informs us of several cases of damage to olive trees, although also a number of cases report on trees growth enhancement due to direct irrigation with OMW (personal communication with farmers and olive mills owners). Likely, OMW affects soil fertility due to clogging of soil pores and may affect crops and trees because of its acidity, brought about by biodegradation of the organic compounds in the wastewater.

\section{OMW CHARACTERISTICS IN JORDAN}

There are seventeen three-phase full-automatic olive oil mills distributed over the three districts (Jerash, Merda and Burma) of Jerash governorate with different capacities (2-8 ton/hr). The specific OMW production rate in terms of $\mathrm{m}^{3} \mathrm{OMW} /$ tonnes processed olives in Jerash was attained by site visits (see Table 3). Mill managers provided the figures of the daily water consumption when working 24 hours continuously and the specific OMW production rates were calculated based on:

1. Quantity of processed olives (ton/day) = capacity of the olive mill (ton/h) $\mathrm{x}$ working hours $(\mathrm{h} / \mathrm{d})$

2. OMW production $\left(\mathrm{m}^{3} /\right.$ day $)=$ water consumption $+40 \% \mathrm{x}$ quantity of processed olive (ton $/ \mathrm{h}$ ); the $40 \%$ stands for the percentage of the vegetation water coming out of the processed olives [2].

Table 3. Specific Olive Mill Wastewater Production in Jerash governorate (Jordan)

\begin{tabular}{|c|c|c|c|c|c|c|c|}
\hline 1 & 2 & 3 & 4 & 5 & 6 & 7 & 8 \\
\hline Olive mill & $\begin{array}{l}\text { Production } \\
\text { capacity }\end{array}$ & $\begin{array}{l}\text { Working } \\
\text { hours }+\end{array}$ & $\begin{array}{l}\text { Daily } \\
\text { processed } \\
\text { olives }\end{array}$ & $\begin{array}{l}\text { Vegetation } \\
\text { water }\end{array}$ & $\begin{array}{l}\text { Water } \\
\text { consumption }\end{array}$ & $\begin{array}{l}\text { Total OMW } \\
\text { production }\end{array}$ & $\begin{array}{l}\text { Specific } \mathrm{OMW} \\
\text { production }\end{array}$ \\
\hline \multirow[t]{2}{*}{ \# } & \multirow[t]{2}{*}{ ton $/ \mathrm{h}$} & \multirow[t]{2}{*}{$\mathrm{h}$} & ton/day & $\mathrm{m}^{3} /$ day & \multirow[t]{2}{*}{$\mathrm{m}^{3} /$ day } & $\mathrm{m}^{3} /$ day & $\mathrm{m}^{3} /$ ton \\
\hline & & & Col. $2 \times 3$ & $0.4 \times$ col. 4 & & $\begin{array}{l}\text { Col. } 5+\text { col. } \\
6\end{array}$ & Col. 7/ col. 4 \\
\hline 1 & 2 & 24 & 48 & 20 & 40 & 60 & 1.25 \\
\hline 2 & 6 & 24 & 144 & 60 & 90 & 150 & 1.1 \\
\hline
\end{tabular}

+working hours at the indicated water consumption, i.e. working 24 hours a day is only over a few days of the milling period; typically olive mills work 10-18 hours/day most of the milling period, and work 24 hours/day during around 40 days, viz. during the period $20^{\text {th }}$ November till the end of December.

The calculated specific OMW production of 1.1 and $1.25 \mathrm{~m}^{3}$ per ton is similar to data reported in literature, confirming that this methodology can be used for determining the design flow of the required wastewater treatment systems. Rozzi and Malpei [2] reported specific OMW productions ranging from 0.5 to $1.5 \mathrm{~m}^{3}$ per ton of processed olives.

Chemical agents are not used in the olive oil production in Jerash. Therefore, the OMW characteristics are fully determined by the olive composition and its vegetation water. The factors which influence the quantity and characteristics of the OMW include: type of production process, type of olives, area under cultivation or arable soil, use of pesticides and fertilizers, harvest time or stage of maturity, and climate or weather conditions [18]. 
The OMW characteristics in Jordan as compared to the Jordanian standards and regulations are presented in Table 4. The data shows that OMW is slightly acidic, has a very high concentration of organic matter (BOD, COD, FOG) and TSS and the EC and TDS are very high because of the high mineral content. The high phenolic concentrations found in OMW which may result in inhibition of biological treatment processes [19]. Various pilot plant studies showed that the imposed effluent phenol concentration of $10 \mathrm{mg} / \mathrm{L}$ by the Jordanian standards for the discharge of industrial wastewater to sanitary sewer system was never achieved by conventional biological processes. Therefore some form of pre and/or post treatment processes (aerobic, physic-chemical) will be required and thus proper technical solutions still need to be developed.

Table 4. Characteristics of OMW in Jordan in comparison to Jordanian standards and regulations for the discharge and reuse of industrial wastewater

\begin{tabular}{|c|c|c|c|c|c|}
\hline \multirow[b]{2}{*}{ Parameter } & \multirow[b]{2}{*}{ Units } & & \multicolumn{3}{|c|}{ Maximum Allowable Limit } \\
\hline & & $\begin{array}{c}\text { Average } \\
\text { characteristics } \\
\text { of OMW }\end{array}$ & $\begin{array}{c}\text { Disposal to } \\
\text { Wadis \& } \\
\text { Rivers }\end{array}$ & $\begin{array}{l}\text { Reuse for } \\
\text { Irrigation }\end{array}$ & $\begin{array}{c}\text { Discharge to } \\
\text { Sanitary Sewer } \\
\text { System }\end{array}$ \\
\hline $\mathrm{pH}$ & & 5.67 & $6.5-9.0$ & $6.5-8.4$ & $5.5-9.5$ \\
\hline $\mathrm{EC}$ & $\mu \mathrm{s} / \mathrm{cm}$ & 9,350 & & & \\
\hline TDS & $\mathrm{mg} / \mathrm{L}$ & 39,133 & 3000 & 2000 & \\
\hline TSS & $\mathrm{mg} / \mathrm{L}$ & 29,313 & 50 & 1000 & 1100 \\
\hline TVSS & $\mathrm{mg} / \mathrm{L}$ & 22,844 & & & \\
\hline TFSS & $\mathrm{mg} / \mathrm{L}$ & 6,232 & & & \\
\hline COD & $\mathrm{mg} / \mathrm{L}$ & 117,105 & $150^{+}$ & - & 2100 \\
\hline $\mathrm{BOD}_{5}$ & $\mathrm{mg} / \mathrm{L}$ & 38,048 & $50^{+}$ & - & 800 \\
\hline FOG & $\mathrm{mg} / \mathrm{L}$ & 6,983 & 5 & 5 & 50 \\
\hline T-P & $\mathrm{mg} / \mathrm{L}$ & 272 & & - & \\
\hline $\mathrm{NH}_{4}-\mathrm{N}$ & $\mathrm{mg} / \mathrm{L}$ & 45 & & - & \\
\hline TKj-N & $\mathrm{mg} / \mathrm{L}$ & 704 & & 50 & \\
\hline $\mathrm{Na}$ & $\mathrm{mg} / \mathrm{L}$ & 258 & & - & \\
\hline $\mathrm{Ca}$ & $\mathrm{mg} / \mathrm{L}$ & 420 & & & \\
\hline $\mathrm{Mg}$ & $\mathrm{mg} / \mathrm{L}$ & 52 & & & \\
\hline K & $\mathrm{mg} / \mathrm{L}$ & 3,599 & & & \\
\hline $\mathrm{Cl}$ & $\mathrm{mg} / \mathrm{L}$ & 734 & 500 & 350 & \\
\hline $\mathrm{HCO}_{3}$ & $\mathrm{mg} / \mathrm{L}$ & 3,086 & - & 500 & \\
\hline Phenol & $\mathrm{mg} / \mathrm{L}$ & 3,402 & 0.002 & 0.002 & 10 \\
\hline
\end{tabular}

Sources: [7]; ${ }^{+}$Monthly average; - Undetermined

Pollution prevention firstly starts with introducing the cleaner production approach by technical rearrangements in the milling process, i.e. reducing the OMW pollution load. Secondly, cleaner production can be achieved by modifying the three phase decanters to two and a half phase decanters or replace them by a two phase decanters. Minimising wastewater flows has a direct economic benefit for the mills since it reduces the costs for tanker transport. 


\section{CENTRALISED VS. DECENTRALISED SYSTEMS}

The treatment and disposal of OMW is carried out either directly at the mill or at a centralised treatment plant. Centralised treatment plants have the advantage of economy of scale and are generally operated by specialised staff which can guarantee a better performance than on-site mill operators [2]. However, costs for conveyance of the wastewater to centralised systems are much more expensive. As earlier described, a wide conveyance network might encounter operational problems due to the acidity and high solids content of the OMW, which will impose additional costs for maintenance.

Ammary [20] pointed that onsite treatment of OMW in Jordan is more cost effective than building large central treatment plants treating OMW from scattered mills. The olive mills in Jerash already have to comply with regulations demanding onsite collection tanks to store the produced OMW. At the moment these storage tanks are frequently emptied by vacuum tankers that travel for along distance, ca. $50 \mathrm{~km}$, in order to dispose their load at an authorized dumping site located at the eastern desert area of Jordan. A vacuum tanker of $15 \mathrm{~m}^{3}$ capacity charges around 30 US\$ per load.

\section{CONCLUSIONS AND RECOMMENDATIONS}

Olive mill wastewater is much polluted with exceptionally high organic pollution loads. Phenolic compounds are among the most problematic compounds in terms of removal sop as to comply with Jordanian discharge standards. Nonetheless, olive trees cultivation and olive oil extraction are an ever increasing agro-industrial activity in Jordan, which urgently necessitates a parallel development and application of proper waste management technologies and concepts.

It is recommended to examine the technical and socio-economic aspects of modifying the three phase decanters to two and a half phase decanters or replace them by a two phase decanters, as this will reduce the water consumption and subsequent wastewater production.

\section{REFERENCES}

[1] Dalis, D., Anagnostidis, Lopez, A., Letsiou, I., Hartmann, L., 1996. Anaerobic digestion of total raw olive-oil wastewater in a two-stage pilot-plant (up-flow and fixed-bed bioreactors). Biores. Technol., 57, 237-243.

[2] Rozzi, A., Malpei, F., 1996. Treatment and disposal of olive mill effluents. Intern. Biodeterior. Biodegrad., 135-144.

[3] Benitez, F. J., Beltran-Heredia, J., Torregrosa, J., Acero, J. L., 1997. Aerobic degradation of olive mill wastewater. Appl. Microbiol. Biotechnol., 47, 185-188.

[4] Beccari, M., Bonemazzi, E., Majone, M., Riccardi, C. 1996. Interactions between acidogenesis and methanogenesis in the anaerobic treatment of olive mill effluents. Water Res., 30, 183-189.

[5] Casa, R., D’Annibale, A., Pieruccetti, F., Stazi, S. R., Sermani, G., Lo Cascio, B., 2003. Reduction of the phenolic components in olive-mill wastewaters by an enzymatic treatment and its impact on durum wheat (Triticum durum Desf.) germinability. Chemosphere, 50, 959-966.

[6] Adhoum, N., Monser, L., 2004. Decolourization and removal of phenolic compounds from olive mill wastewater by electrocoagulation. Chem. Eng. Process., 43, 1281-1287. 
[7] RSS, 1997. Wastewater from olive mills: reducing environmental impacts (Jordan). Final technical report presented to the International Development Research Centre (IDRC)Canada by Royal Scientific Society (RSS), Environmental Research centre (ERC), Studies and Design Division, Amman, Jordan.

[8] Agricultural Statistics, 2002. Agricultural Statistics, Department of Statistics, Amman, Jordan.

[9] Raposo, F., Borja, R., Sánchez, E., Martín, M. A., Martin, A., 2004. Performance and kinetic evaluation of the anaerobic digestion of two-phase olive mill effluents in reactors with suspended and immobilised biomass. Water Res., 38, 2017 - 2026.

[10] Azbar, N., 2004. A review of waste management options in olive oil production. Crit. Rev. Envirn. Sci. Technol., 34, 209 - 247.

[11] Raposo, F., Borja, R., Sánchez, E., Martín, M. A., Martin, A., 2003. Inhibition kinetics of overall substrate and phenolics removals during the anaerobic digestion of two-phase olive mill effluents (TPOME) in suspended and immobilized cell reactors. Process Biochem., 39, 425 - 435.

[12] Vossen, P., 2000. http://cesonoma.ucdavis.edu/HORTIC/italy_report.pdf

[13] Wikipedia, 2006. http://en.wikipedia.org/wiki/Olive oil extraction

[14] Balice, V., Boari, G., Cera, O., Abbaticchio, P., 1982. Indagine analitica sulle acque di vegetazione. Nota 1. Inquinamento, 6-7, 49-53.

[15] Ramos-Comenzana, A., Monteolica-Sanchez, M., Lopez, M. J., 1995. Biodegradation of alpechin. I. Biodeter. Biodegr., 35, 249-268.

[16] Sabbah, I., Marsook, T., Basheer, S., 2004a. The effect of pretreatment on anaerobic activity of olive mill wastewater using batch and continuous systems. Process Biochem., 39, 1947-1951

[17] Boari, A., Brunetti, A., Passino, R., Rozzi, A., 1984. Anaerobic digestion of olive oil mill wastewaters. Agricultural Wastes, 10, 161-175.

[18] EC, European Commission, 2000. Improvements of Treatments and Validation of the Liquid-Solid Waste from the Two-Phase Olive Oil Extraction, Project Improlive, Programme FAIR CT96-1420, Final Report, Annex A2, 72 pp. Available on BioMat Net Website www.nf-2000.org.

[19] Field, J.A., 1989. The effect of tannic compounds on wastewater treatment. PhD thesis, Sub-department of Environmental Technology, Wageningen University, The Netherlands, pp. 199.

[20] Ammary, B.Y., 2005. Treatment of olive mill wastewater using an anaerobic sequencing batch reactor. Desalination, 177, 157-165. 